\title{
Evolution of Physical and Chemical Properties of Water Quality in Pithampur Industrial Zone
}

\author{
Paras Tak $^{1}$, Madhaw Singh Chouhan ${ }^{2}$ \\ ${ }^{1}$ Pacific Academy of Higher Education and Research University, Udaipur Rajasthan, India \\ parastak2011@gmail.com \\ ${ }^{2}$ Shahid Chandrashekhar Azad Govt. P. G. College, Jhabua M. P., India \\ madhaw1975@gmail.com
}

\begin{abstract}
Pithampur Industrial area also known as "Detroit of India". There are tremendous types of industries in Pithampur Industrial area. Due to industrialization, the quality of water may always sensitive, because some industries do not have proper treatment system and they discharge untreated water in outer their premises. In this study number of samples and parameters were analyzed. This study is helpful for many stakeholders to make proper planning.
\end{abstract}

Keywords: Detroit of India, pH, Sp. Conductivity, Total Hardness, BOD, COD, DO, Heavy Metals, Talab, River, Tube well, Effluent

\section{Introduction}

Good water quality is essential for the well - being of all people. [1] It helps in the growth of the entire organism containing life on earth. Of all the matter present in the earth water is said to be above all because it gives life and without this we would not be able to survive even for a second. [2] It is said that "Water is more precious than gold and more explosive than dynamite". As we all know that water should be checked before its consumption because consumption of water containing impurities will cause various water borne diseases. Therefore all the parameters should be compared with the guidelines prescribed by Bureau of Indian Standards and World Health Organization before consuming it as a drinking, domestic, industrial, recreation and irrigation purposes etc [3] In many developing countries, availability of water has become a critical and urgent problem and it is a matter of great concern to families and communities depending on non - public water supply system [4]. Increase in human population exerts an enormous pressure on the provision of safe drinking water especially in developing countries [5]. In India disposal of untreated domestic sewage from cities, towns and villages is the major source of pollution of surface water bodies leading to the outbreak of water borne diseases. Biodegradable organic matter is the contaminant of concern for dissolved oxygen concentration, which is the principle indicator of pollution of surface water [6]. Over the last few decades, in order to assess the water quality in a water body, researchers from the different parts of the world have developed a number of methodologies like NSFWQI [7], Water Quality Index of Central Pollution Control Board [8], comprehensive pollution index (CPI) [9 - 11] Overall Index of Pollution [12], eutrophication index (EI) [13], organic pollution index (OPI) [14], etc. based on the water quality parameters. However, there is no any universal water quality assessment model available which can be widely acceptable and comparable [15]. The term water quality was developed to give an indication of how suitable the water is for human consumption [16] and is widely used in multiple scientific publications related to the necessities of sustainable management [17].

\subsection{Study Area}

Pithampur is a town of District Dhar lays in the Malwa region of west Madhya Pradesh in Central India. The district Dhar surrounded by the districts of Ratlam to the north, Ujjain to the northeast, Indore to the east, Khargone to the southeast, Barwani to the south, and Jhabua to the west. It is part of the Indore and division of Madhya Pradesh. Pithampur is a large industrial area under the Dhar District. The town is located $908 \mathrm{ft}$ above the sea level. Pithampur has close proximity to Indore. Presently called the 'Detroid of India', and once called the 'Detroit of India', Pithampur houses major industries and companies of Madhya Pradesh. There are 4 Sector and 2 Special Economic Zone (SEZ) in Pithampur Industrial area. [18] 


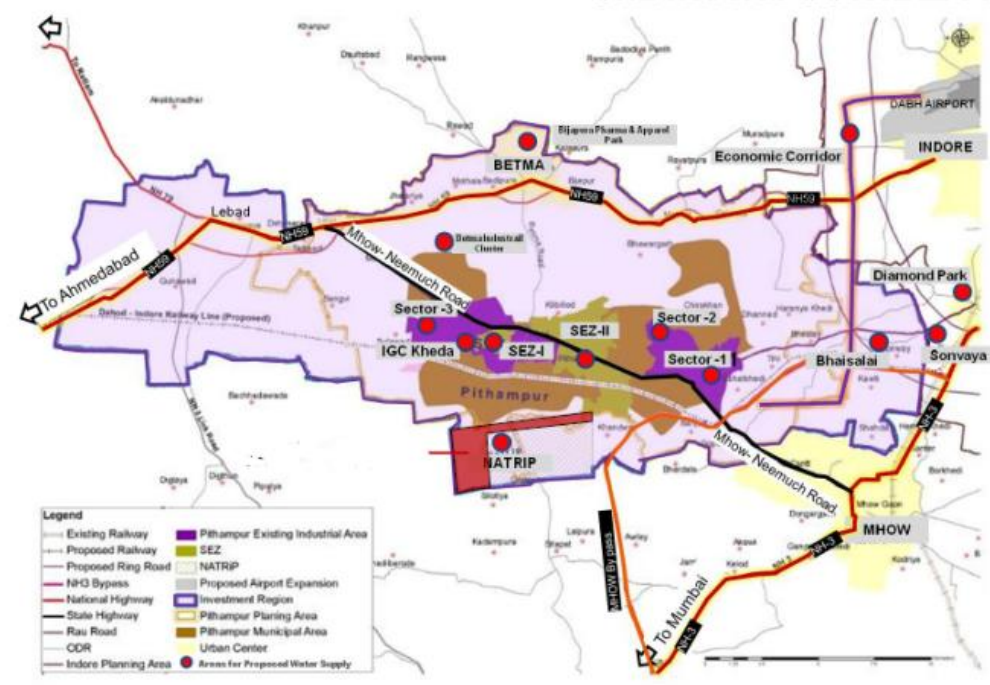

Figure 1: Showing the Pithampur Industrial Area

\section{Material and Method}

\subsection{Site Selection for Sampling}

For the present study, there were 05 Surface water (02 river water, 01 nallahs water, 02 lakes water) and three ground water sources were selected. The selection of the sampling points was based on the survey and accessibility of the sampling sites during the year 2016 - 2017. These locations were:

a) Nallah water at Sector - I, Pithampur (Distt. - Dhar): This site was situated at near VE Commercial Industries Ltd., Industrial Area, Sector 1, Pithampur.

b) Angred River D/S, Pithampur (Distt. - Dhar): This site is situated at Achna Village. Here is confluence point of River Angred and River Chambal.

c) Sanjay Jalashay, Pithampur: This pond is situated in the vicinity of Pithampur Industrial Area and is alongside the Agra - Mumbai National Highway No.3. A few villages are present in the vicinity of this sampling location also indicating a little probability of waste water discharge in the pond. It is main water supply source of the Pithampur area.

d) Bagdoon Talab: This pond is situated in the Vijay Nagar colony Sector - 3. Many industries were present around this pond. This pond indicating high probability of waste water discharge in the pond.

e) Tube well water at Vishwas Nagar, Pithampur (Distt. Dhar): This Tube well was in the Vishwas Nagar, Pithampur. This site was representing the ground water source and was selected because it was nearby the industries.

f) Hand pump water at Vill - Kheda, Pithampur (Distt. Dhar): This Hand pump was in the Vill. - Kheda, Pithampur. This site was representing the ground water source and was selected because it was nearby the major polluting industries.

g) Tube well water at Sagour Kuti, Pithampur (Distt. Dhar): This site was situated in the Sagoure Kuti near industrial area, Sector - 3.

h) River Chambal (5 kms D/s) (Distt. - Dhar): This site was situated at Ghatabillod, which is a town of District Dhar.
National Highway 47 and State Highway 31 passes through Ghatabillod.

\subsection{Sampling Frequency}

Madhya Pradesh has 03 distinct season's viz. winter, summer, and the monsoon. The samples were collected ones time in each season's viz. in winter, summer and rains from all the sampling locations simultaneously. One sample was collected from each location in each season and total of 24 samples were collected from the eight locations in a year. Table 1 shows the sampling details and sites.

Table 1: Description of sampling locations

\begin{tabular}{|c|c|c|}
\hline Sample code & Location name & Coordination \\
\hline S - 1 & Nallah water at Sec - I, Pithampur & $\begin{array}{c}22.610982, \\
75.673471\end{array}$ \\
\hline \multirow{2}{*}{ S - 2 } & Angred River D/S, Pithampur & $\begin{array}{c}22.584491, \\
75.544668\end{array}$ \\
\hline \multirow{2}{*}{ S - 3 } & Sanjay Jalashay & 22.592833, \\
& Bagdoon Talab & 22.673002 \\
\hline \multirow{2}{*}{ S - 4 } & Tube well water at Vishwas & 75.587340 \\
\hline \multirow{2}{*}{ S - 5 } & Nagar, Pithampur (Distt. - Dhar) & 22.593799, \\
& Hand pump water at Vill - & 22.693370 \\
\hline \multirow{2}{*}{ S - 6 } & Kheda, Pithampur (Distt. - Dhar) & 75.623740 \\
\hline \multirow{2}{*}{ S - 7 } & Tube well water at Sagor Kuti, & 22.606850, \\
& Pithampur (Distt. - Dhar) & 75.683788 \\
\hline \multirow{2}{*}{ S - 8 } & River Chambal (5km) (Distt. - Dhar) & 22.660570, \\
& & \\
& &
\end{tabular}

\subsection{Analysis Protocols and Lab Methods for Analysis}

Samples were collected directly in pre - washed and rinsed, polyethylene/glass containers identified for Respective parameters. Stipulated procedure was followed for washing of sample containers. Field parameters like Temperature, $\mathrm{pH}$ and dissolve oxygen, which are non conservative and could not be preserved, were analyzed immediately after collection was per standard procedure. Samples were analyzed based on the standard procedures of water analysis of bacteriological and physicochemical parameters [19] [20]. 
Table 2: Water quality parameters and analytical methods for water source evaluation

\begin{tabular}{|c|c|c|}
\hline Parameters & Analytical Method & Instrument \\
\hline Temperature & Instrument, analyze on site & Thermameter \\
\hline $\mathrm{pH}$ & Analyze on site & $\mathrm{pH}$ meter strip \\
\hline Conductivity & Analyze on site & \\
\hline Total Hardness & EDTA Titrimetric Method & \\
\hline $\mathrm{DO}$ & Analyze on site & Azide Modification \\
\hline BOD & Winkler's Method & \\
\hline $\mathrm{COD}$ & Open Reflux Method & \\
\hline Iron & \multirow{7}{*}{ Analyzed on AAS instrument } & \\
\hline Manganese & & \\
\hline Lead & & \\
\hline Copper & & \\
\hline Chromium & & \\
\hline Zinc & & \\
\hline Lead & & \\
\hline
\end{tabular}

The 14 parameters were analyzed during the study period. The methods of these parameters are -

\subsubsection{Temperature}

One of the most important factors is temperature. Dissolve Oxygen is influenced by this factor.

\subsection{2 pH Test}

$\mathrm{pH}$ was measured on a logarithmic scale between 1 and 14 with 1 being extremely acid, 7 neutral and 14 extremely basic. The largest variety of freshwater aquatic organisms prefers a $\mathrm{pH}$ range 6.5 to 8.0. Samples were tested with Universal Indicator and with $\mathrm{pH}$ meter.

\subsubsection{Specific Conductivity}

This is a measure of the capability of a solution such as water in a stream to pass an electric current. This is an indicator of the concentration of dissolved electrolyte ions in the water. It doesn't identify the specific ions in the water. However, significant increases in conductivity may be an indicator that polluting discharges have entered the water. Higher conductivity will result from the presence of various ions including nitrate, phosphate, and sodium. Samples were tested in Conductivity meter. The basic unit of measurement for conductivity is micromhos per centimeter $(\mu \mathrm{mhos} / \mathrm{cm})$ or microsiemens per centimeter $(\mu \mathrm{S} / \mathrm{cm})$.

\subsubsection{Total Hardness}

Total hardness is computed by sum of temporary hardness and permanent hardness. The sources of hardness of water is chiefly due to the dissolve of $\mathrm{OH}^{-}, \mathrm{HCO}^{-}, \mathrm{Cl}^{-}$and $\mathrm{SO}^{-}$ion of $\mathrm{Ca}^{+}, \mathrm{Mg}^{+}, \mathrm{Fe}^{+}$and $\mathrm{Mn} 2^{+}$. The usual signs of a hard water supply are scaling inside kettles, poor lathering of soaps and scum. Hard water is formed when water passes through or over limestone or chalk areas and calcium and magnesium ions dissolve into the water.

\subsubsection{Dissolved Oxygen}

Dissolved Oxygen is oxygen gas molecules $\left(\mathrm{O}_{2}\right)$ present in the water. Plants and animals cannot directly use the oxygen that is part of the water molecule $\left(\mathrm{H}_{2} \mathrm{O}\right)$, instead depending on dissolved oxygen for respiration. Oxygen enters streams from the surrounding air and as a product of photosynthesis from aquatic plants. Consistently high levels of dissolved oxygen are best for a healthy ecosystem.
Dissolved oxygen was measured in $\mathrm{mg} / \mathrm{L}$.

\subsubsection{COD}

COD is a measure of the oxygen required for the chemical oxidation of organic matter with the help of strong chemical oxidant. High COD may cause oxygen depletion on account of decomposition of microbes to a level detrimental to aquatic life. COD determination has an advantage over BOD determination in that the result can be obtained in about 5 hours as compared to 5 days required for BOD test.

\subsubsection{BOD}

Biochemical oxygen demand, is a bioassay procedure that measures the dissolved oxygen (DO) consumed by bacteria from the decomposition of organic matter. The BOD analysis is an attempt to simulate by a laboratory test the effect that organic material in a water body will have on the DO in that water body.

\subsubsection{Heavy Metals}

In this study there are six metals were analyzed namely Iron ( $\mathrm{Fe})$, Manganese (Mn), Lead ( $\mathrm{Pb})$, Chromium (Cr), Copper $(\mathrm{Cu})$, Zinc $(\mathrm{Zn})$. Digestion of Samples for the Analyses of metals in the laboratory, the samples was filtered through Whatman's $0.45 \mu \mathrm{m}$ membrane filter paper. One hundred milliliters of the filtered water was mixed with $5 \mathrm{~mL}$ concentrated nitric acid $\left(\mathrm{HNO}_{3}\right)$ and $5 \mathrm{~mL}$ concentrated sulphuric acid $\left(\mathrm{H}_{2} \mathrm{SO}_{4}\right)$. To allow the acids to become concentrated, the mixture was heated until the volume was reduced to about 15 to $20 \mathrm{~mL}$. The digested sample was allowed to cool to room temperature. It was then filtered through Whatman's $0.45 \mu \mathrm{m}$ filter paper. The final volume was adjusted to $100 \mathrm{~mL}$ with double distilled water and stored for analysis. [18]

Table 3: Water quality parameters and analytical methods for water source evaluation

\begin{tabular}{|c|c|c|c|}
\hline S. No & Parameters & Unit & Test Method \\
\hline 1 & Temperature & ${ }^{\circ} \mathrm{C}$ & Thermometer \\
\hline 2 & $\mathrm{pH}$ & - & $\mathrm{pH}$ meter \\
\hline 3 & B. O. D. & $\mathrm{mg} / \mathrm{L}$ & $\begin{array}{r}\text { Three day incubation and } \\
\text { titration of initial and final D. O. }\end{array}$ \\
\hline 4 & Dissolved Oxygen & $\mathrm{mg} / \mathrm{L}$ & Winkler Method \\
\hline 5 & $\begin{array}{r}\text { Chemical Oxygen } \\
\text { Demand }\end{array}$ & $\mathrm{mg} / \mathrm{L}$ & Open Reflux Method \\
\hline 6 & Sp. Conductivity & $\mathrm{mg} / \mathrm{L}$ & Conductivity meter \\
\hline 7 & Total Hardness & $\mathrm{mg} / \mathrm{L}$ & EDTA Titration \\
\hline 8 & Heavy Metals & $\mathrm{mg} / \mathrm{L}$ & Atomic Absorption Spectroscopy \\
\hline
\end{tabular}

\section{Results and Discussion}

\subsection{Temperature}

The average water temperature varied from $19.1^{\circ} \mathrm{C}$ to $31.2^{\circ} \mathrm{C}$. During winter month the water temperature were found to be minimum, whereas the summer month exhibited the maximum water temperature. This investigation is also in close conformity with the finding of Kannan and Job (1979), Moundiotiya et al (2004), Mishra et al (2008), Sharma and Capoor (2010), and Arya et al (2011).

In the present study the temperature value were measured on the spot. The minimum temperature value recorded in $\mathrm{S}-6$ 
and the maximum Temperature value recorded in $S-4$ in summer season, as shown in Fig.2

\section{2 $\mathrm{pH}$ value}

It is known that $\mathrm{pH}$ of water does not has direct effect on health. But lower value below 5.0 produces sore taste and has higher value above 8.5 and alkaline taste [21] In the present study the $\mathrm{pH}$ range were found between $6.9-8.49$. The minimum $\mathrm{pH}$ values were found in $\mathrm{S}-4$ (surface water) in winter season, and the maximum values were found also in S - 4 (surface water) in summer season. As shown in Fig.3

\subsection{Specific Conductivity}

Electrical conductivity estimates the amount of total dissolved salts or the total amount of dissolved ions in the water [22]. In the present study S - 7 sampling station in summer season showed higher values of Electrical conductance and Increasing levels of conductivity and cations are the products of decomposition and mineralization of organic materials. The minimum conductivity found in $\mathrm{S}$ 3 sampling station in rainy season as shown in $\mathrm{g}$ Fig.4

\subsection{Total Hardness}

Hardness is frequently used as an assessment of the quality of water supplies. Water with Hardness above $200 \mathrm{mg} / \mathrm{L}$. may cause scale deposition in the distribution system and results in excessive soap consumption and subsequent scum formation. Soft water with hardness of less than $100 \mathrm{mg} / \mathrm{L}$. may have lower buffer capacity and more corrosive to water pipes [23]. In the present study the value of Total Hardness were found in range between $100 \mathrm{mg} / \mathrm{L}$. - $1000 \mathrm{mg} / \mathrm{L}$. The minimum value of Hardness was showed in $\mathrm{S}-3$ sampling station and maximum in $\mathrm{S}-7$.

In Winter session four samples $\mathrm{S}-2, \mathrm{~S}-4-\mathrm{S}, \mathrm{S}-5, \mathrm{~S}-6$ crossed the Desirable limit of Total Hardness (200 mg/L.) and one sample crossed the permissible limit of Total Hardness (600 mg/L.). In Summer session four samples crossed the limit of Total Hardness, S - 2, S - 4, S - 5 and S 8, while two samples $S-6$ and $S-7$ cross the permissible limit of Hardness (600 mg/L.). In Rainy season Three samples crossed Desirable limit of Total Hardness S - 2, S S - 5, and S - 8 while two sampled S - 6 and $S-7$ crossed the permissible limit of Hardness $(600 \mathrm{mg} / \mathrm{L}$.) as prescribed in Indian standard. As shown in Fig.5

\subsection{Dissolve Oxygen}

Dissolved Oxygen in water is of great importance to all aquatic organisms and is considered to be the factor that reflects the biological activity taking place in a water body as it determines the biological changes. [24]. In the present study the concentration of $\mathrm{D}$. O. were found in range between $2.0 \mathrm{mg} / \mathrm{L}$. - $6.6 \mathrm{~m} / \mathrm{L}$. The minimum D. O. were found in $\mathrm{S}-2$ (surface water) water sample, in summer session and maximum in $\mathrm{S}-8$ (surface water) water sample in winter session. In all sampling station D. O. were found in good concentration. Fig.6

\subsection{Biological Oxygen Demand}

B. O. D. concentrations were found between $1 \mathrm{mg} / \mathrm{L}$. - 140 $\mathrm{mg} / \mathrm{L}$. It was found in the range $1.1-80.81 \mathrm{mg} / \mathrm{L}$. in winter, $1.3-140$ in summer while $1-50.11$ in rainy session. The higher values of BOD mean presence of more biodegradable organic material (ICMR, 1975). Fig.7

\subsection{Chemical Oxygen Demand}

COD is a measure of the oxygen required for the chemical oxidation of organic matter with the help of strong chemical oxidant. High COD may cause oxygen depletion on account of decomposition of microbes to a level detrimental to aquatic life. COD determination has an advantage over BOD determination in that the result can be obtained in about 5 hours as compared to 5 days required for BOD test. [25]

In this present study the concentration of C. O. D. were found in range between $6.98 \mathrm{mg} / \mathrm{L}-620 \mathrm{mg} / \mathrm{L}$. In rainy session minimum COD were found in S5 station and maximum in $\mathrm{S} 1$, in summer session minimum in 11.13 and maximum in S1, while in winter session the minimum in S5 and maximum in S1 station. Fig.8

\subsection{Metals}

\section{a) Iron}

Concentration of Iron in water get increased by corrosion of pipes and by of iron present in soil by acidic water. Kidney stone related problem may develop if calcium and iron contents are high. [26]

The Iron Concentration ranges from 0.01 to $0.31 \mathrm{mg} / \mathrm{L}$. In winter $\mathrm{S}-1, \mathrm{~S}-2, \mathrm{~S}-5, \mathrm{~S}-7, \mathrm{~S}-8$ sampling point crossed the Desirable Limit of $\mathrm{Fe}(0.03 \mathrm{mg} / \mathrm{L})$ as prescribed by Indian Standard. In Summer Session all the sampling point crossed the Desirable limit and in rainy session $\mathrm{S} 1$ and $\mathrm{S} 2$ sampling point crossed the Desirable limit. Fig. 9

\section{b) Manganese}

Concentration obtained for manganese lies in the range 0.001 to $0.290 \mathrm{mg} / \mathrm{L} . \mathrm{S}-1$ in winter session, $\mathrm{S}-1, \mathrm{~S}-2$ and $\mathrm{S}-4$ in summer season, $\mathrm{S}-1, \mathrm{~S}-2, \mathrm{~S}-4$ in rainy session crossed desirable limit $(0.1 \mathrm{mg} / \mathrm{L})$. Fig. 10

\section{c) Lead}

Lead concentration of water samples varies from 0.002 to 0.163. $S-1, S-2$ and $S-8$ in winter session crossed the desirable limit of Lead. S - 1 and $S-2$ in summer session and $\mathrm{S}-1$ in rainy session crossed the desirable limit of Lead $(0.01 \mathrm{mg} / \mathrm{L})$ prescribed by Indian Standards for Drinking Water. (0.01). Fig.11

\section{d) Copper}

The desirable limit of Copper is $0.05 \mathrm{mg} / \mathrm{L}$. Copper concentrations were found only two sampling sites $\mathrm{S}-1$ and $\mathrm{S}-2$ in summer session and it's crossed the desirable limit. Fig.12

\section{e) Chromium}

The concentration of Chromium in water samples varies from 0.001 to 0.091 . Only $\mathrm{S}-1$ in winter and summer 
session crossed the desirable limit of Chromium (0.05 mg/L) as prescribed in Indian standard. Fig.13

\section{f) Zinc}

The desirable limit for Zinc is $5.0 \mathrm{mg} / \mathrm{L}$ as prescribed by Indian Standards for Drinking Water. The concentration for zinc varies from 0.001 to $0.639 \mathrm{mg} / \mathrm{L}$. There are none of the sampling point crossed the permissible limit of Zinc (5) $\mathrm{mg} / \mathrm{L}$ as prescribed in Indian standard. Fig. 14

The graphical representation of different parameters at all the eight sampling locations is shown in Figure 2 to 14

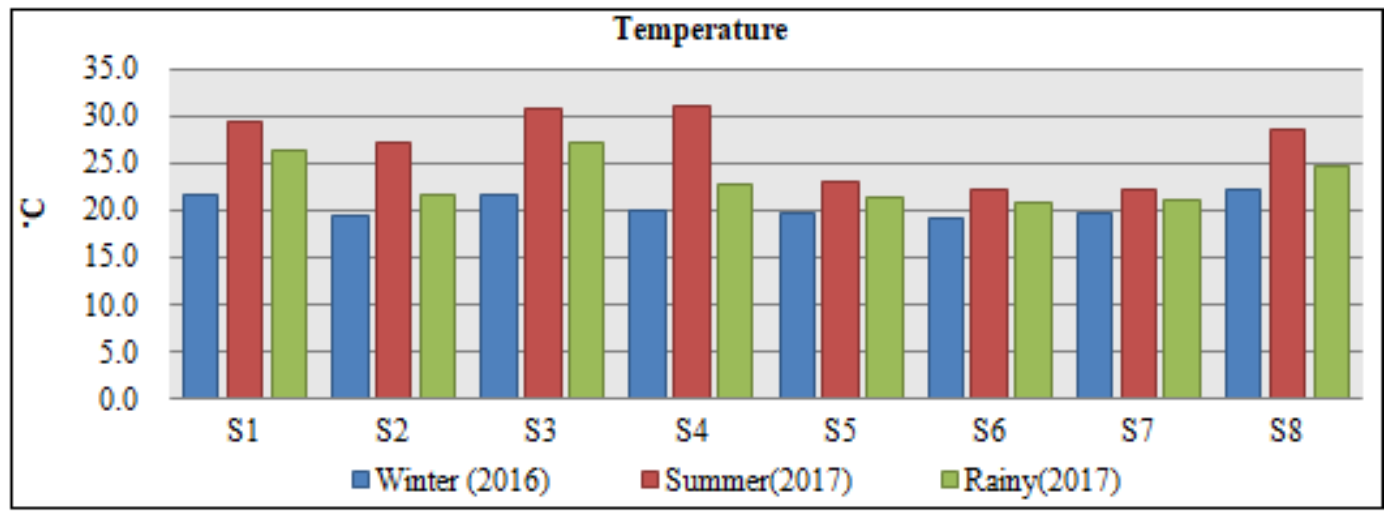

Figure 2: Season wise graphical comparative of Temperature from S1 - S8 for the year 2016 - 2017

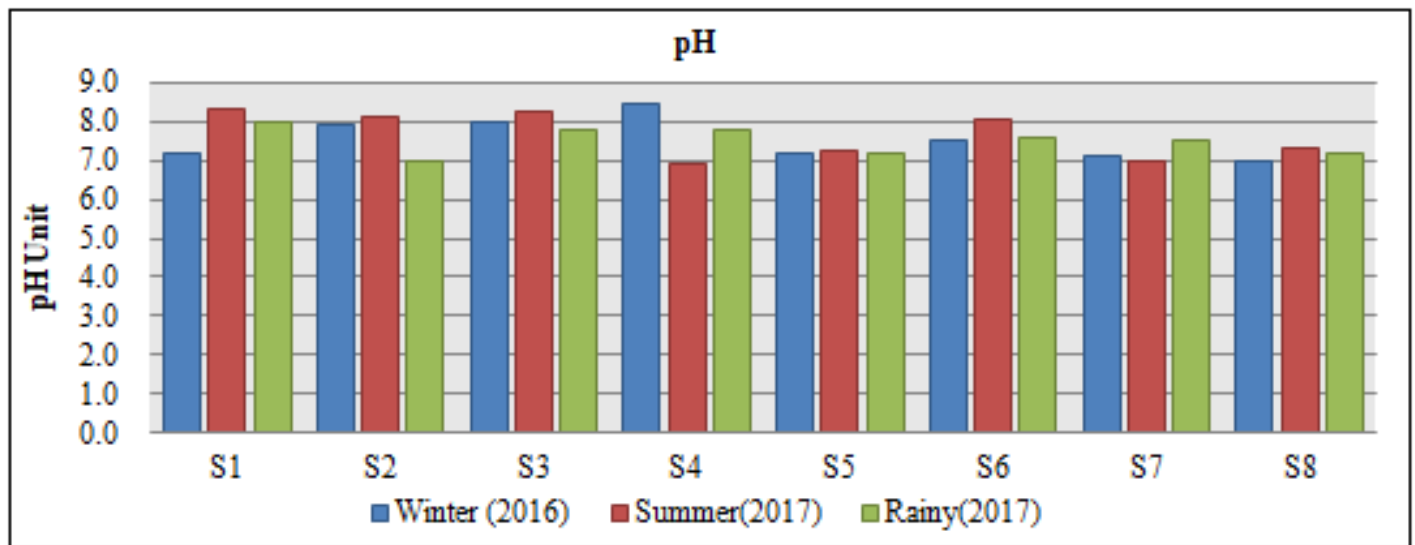

Figure 3: Season wise graphical comparative of pH from S1 - S8 for the year 2016 - 2017

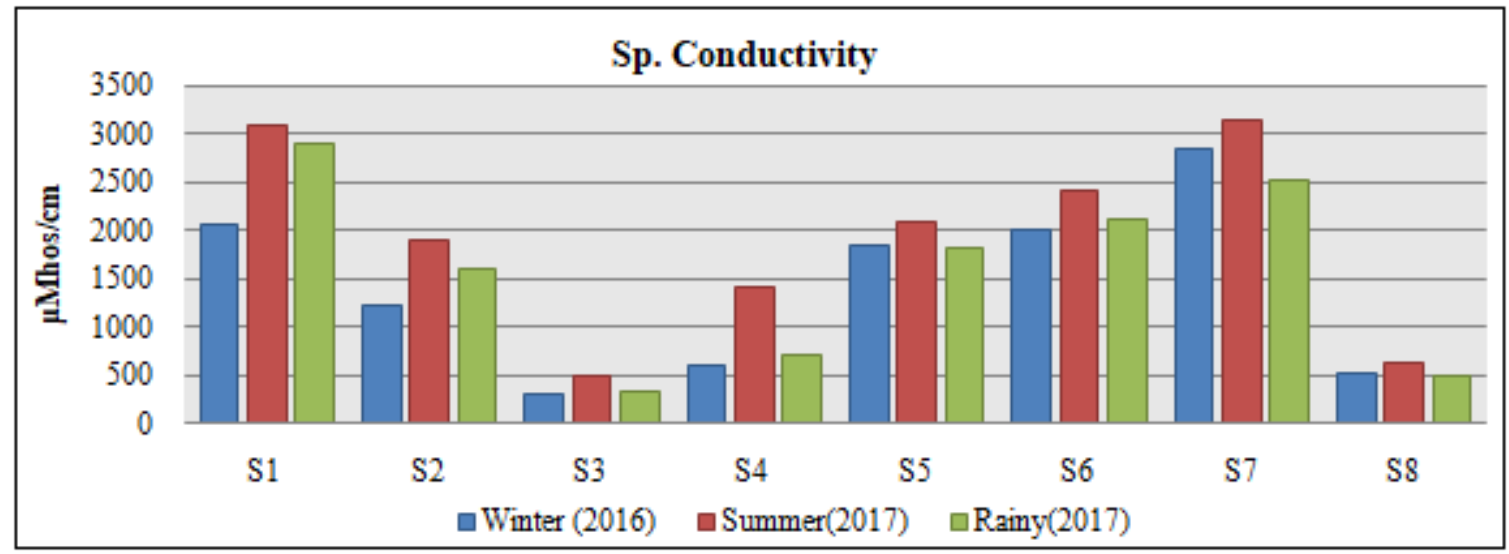

Figure 4: Season wise graphical comparative of Sp. conductivity from S1 - S8 for the year 2016 - 2017 


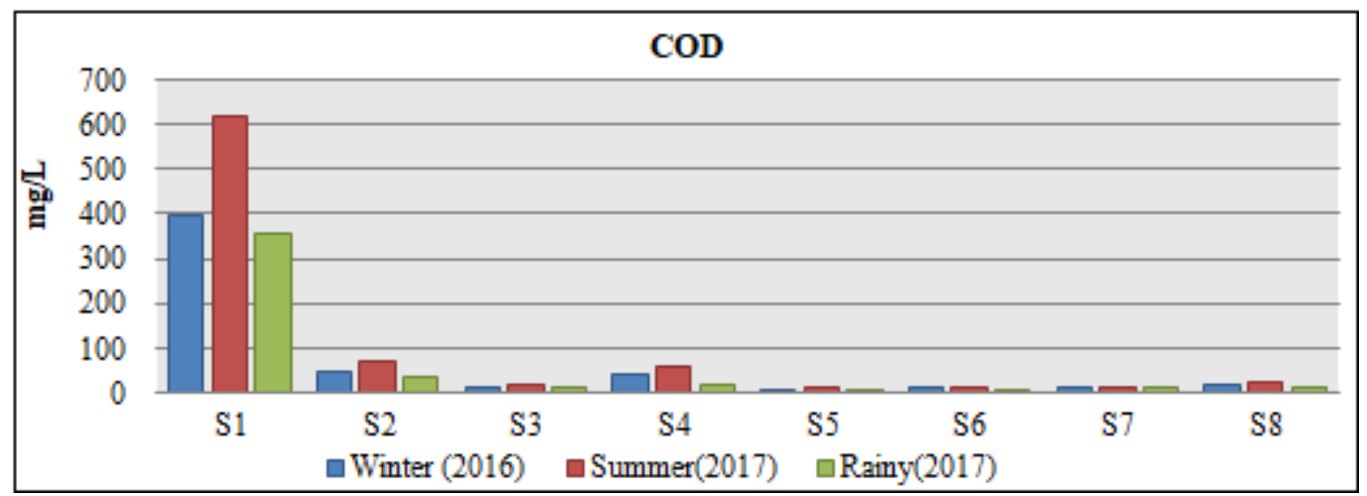

Figure 5: Season wise graphical comparative of C. O. D. from S1 - S8 for the year 2016 - 2017

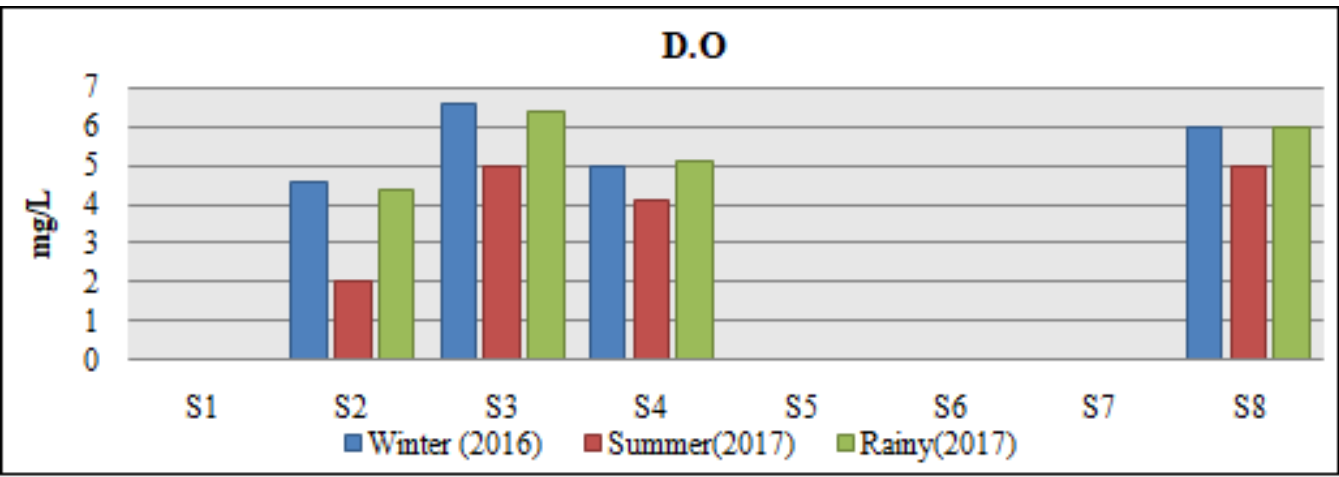

Figure 6: Season wise graphical comparative of D. O. from S1 - S8 for the year 2016 - 2017

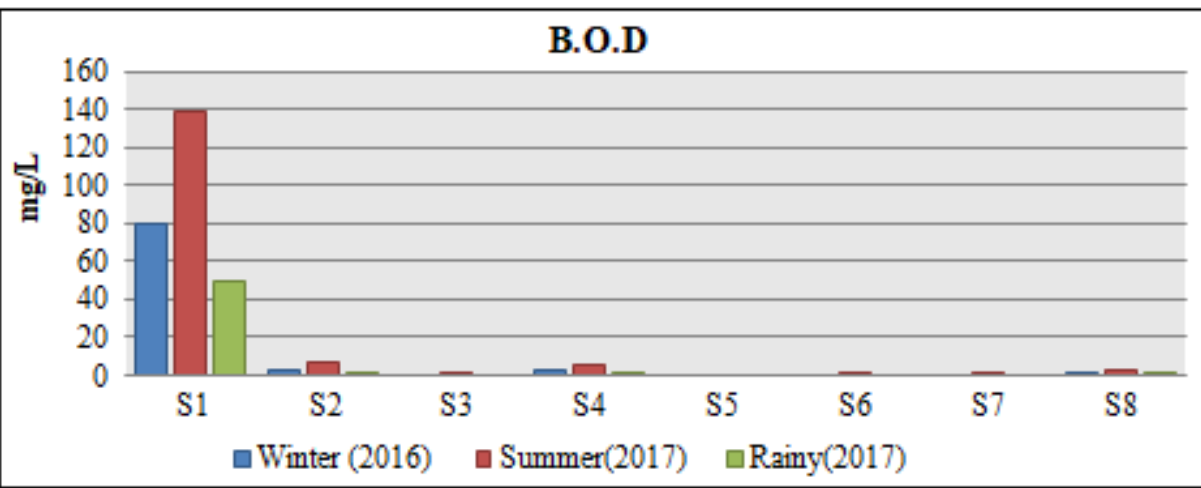

Figure 7: Season wise graphical comparative of B. O. D. from S1 - S8 for the year 2016 - 2017

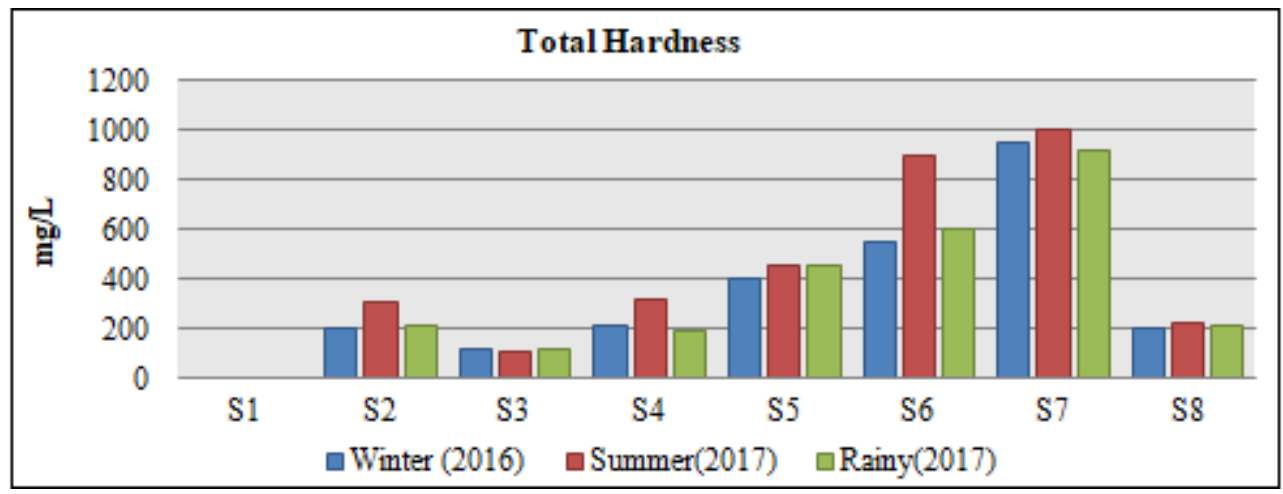

Figure 8: Season wise graphical comparative of B. O. D. from S1 - S8 for the year 2016 - 2017 


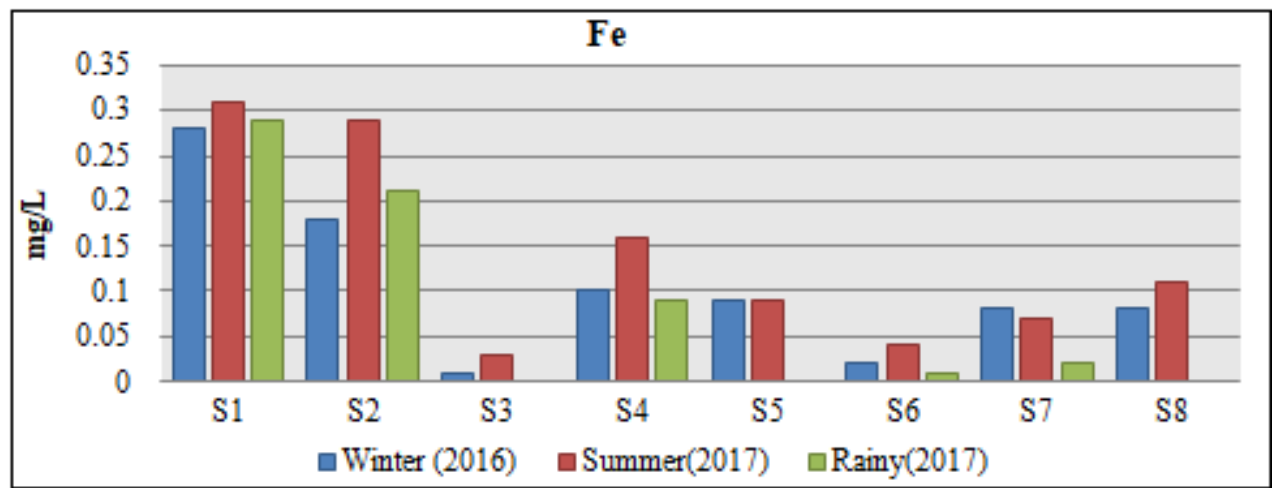

Figure 9: Season wise graphical comparative of Fe from S1 - S8 for the year 2016 - 2017

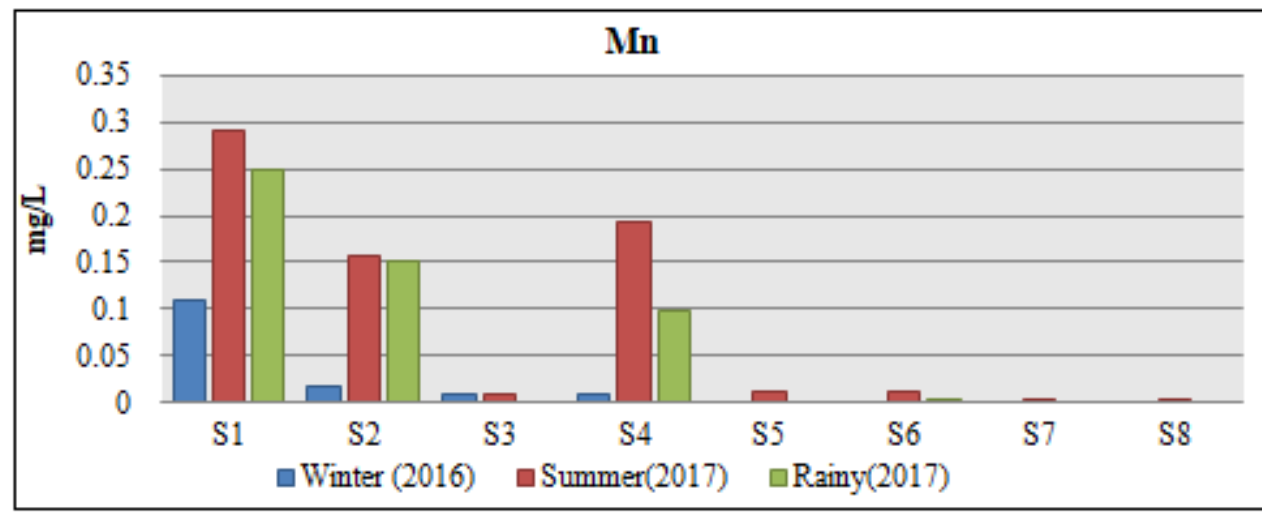

Figure 10: Season wise graphical comparative of Mn from S1 - S8 for the year 2016 - 2017

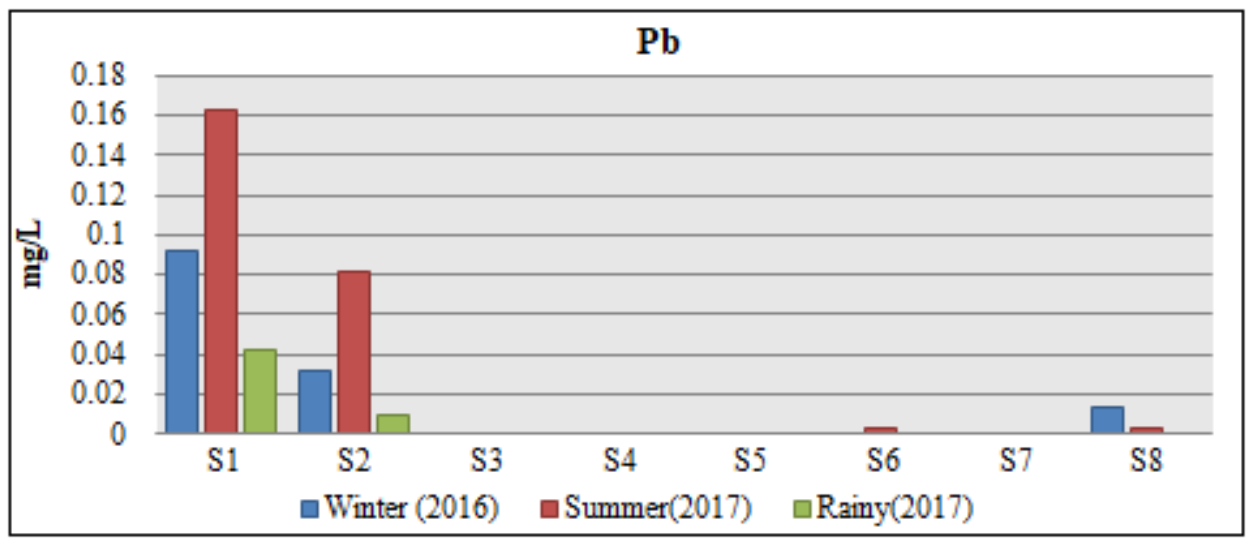

Figure 11: Season wise graphical comparative of Pb from S1 - S8 for the year 2016 - 2017

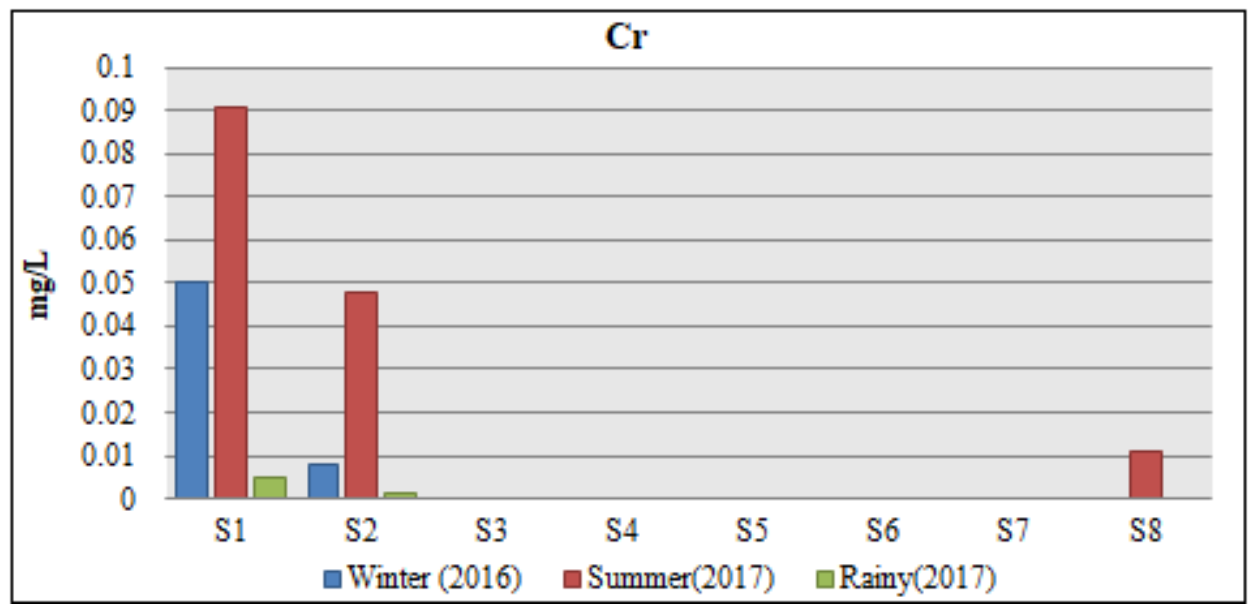

Figure 12: Season wise graphical comparative of Cr from S1 - S8 for the year 2016-2017 


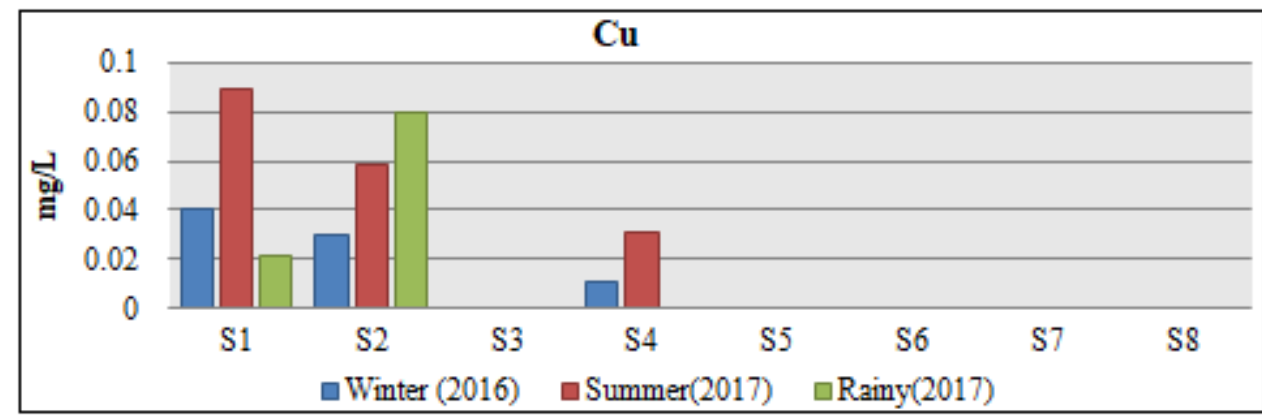

Figure 13: Season wise graphical comparative of Cu from S1 - S8 for the year 2016 - 2017

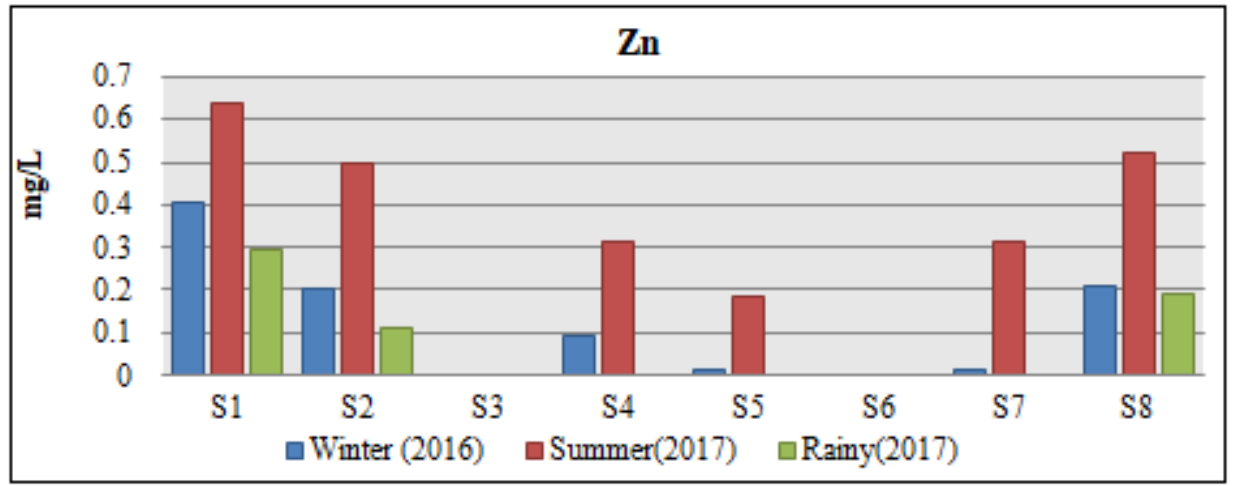

Figure 14: Season wise graphical comparative of Zn from S1 - S8 for the year 2016 - 2017

\section{Conclusion}

The present study leads to following conclusions:

Data indicate that the water quality of Pitahmpur Industrial Area is being deteriorated, it may be due to many industries do not have proper treatment arrangement and they discharge their treated/untreated effluent directly to land, due to this the quality of ground water is spoiled. There are number of Nallahs flowing in Pithampur, many industries discharge their effluent in Nallahs, and the Nallahs joint to the River Angred and then River Chambal.

The analytical data reveals that the quality of ground water, river, and ponds is being contaminated in the industrial area.

\section{References}

[1] Hemant Pathak and S. N. Limaye, Interdependency between physicochemical water pollution indicators: a case study of river Babus, Sagar, M. P., India. Analele UniversităŃii din Oradea - Seria Geografie, 2011, Vol.21 (1), pp.23 - 29.

[2] Nighojkar A. and Chaurasia S. (2017). Water Quality Assessment in Govindgarh Lake of Rewa District (M. P.) - A Review. International Journal of Engineering Research \& Technology, 6 (5), 734 - 735.

[3] Nighojkar A. and Dohare D. (2014). Physico Chemical Parameters for Testing of Present Water Quality of Khan River at Indore, India. Int. Res. J. Environment Sci., 3 (4), 74 - 81.

[4] Okonko Lo., Adejoye Od., Ogunnsi TA., Fajobi EA, Shittu, Microbiological and physico chemical analysis of driffent water sample used for domestic purpose in Abeokuta and Ojota, Lagos stat Nigeria. Afr. J. Biotechnol, 7 (3), 617 - 621 (2008)
[5] Abraham W. R., Megacities as Sources for Pathogenic Bacteria in Rivers, Inter. J. Micro. (2011)

[6] Marta T, Damia B, Roma T. Surface Water Quality indices for the analysis of data generated by automated sampling networks. TrAc Trends. Anal. Chem, 2010; 29 (1): 40 - 52.

[7] Kumar A., Sharma M. P., Yadav N. S., J. Mat. Environ. Sci.5 (2014) 1781 - 1785.

[8] Sarkar C., Abbasi S. A., Environ. Monit. Assess.119 (2006) 201.

[9] Jiang H. H., Zhu J. P., Environ. Monit.15 (1999) 46 47

[10] You Z. J., Lu J. X., Liu Y. Y., Nei. Environ. Sci.21 (2009) $101-102$.

[11] Guo M. M., Environ. Sci. Manag.31 (2006) 175 - 178.

[12] Sargaonkar A., Deshpande V., Environ. Monit. Assess.89 (2003) 43.

[13] Liu S., Lou S., Kuang C., Huang W., Chen W., Zhang J., Zhong G., Marine Poll. Bull.62 (2011) 2220-2229.

[14] Quan W. M., Shen X. Q., Han J. D., Chen Y. Q., Marine Environ. Sci.24 (2005) 13-16.

[15] Shi J., Liu P. G., Zhang L. X., Acta. Oceano. Sin.31 (2009) 99 - 105

[16] H. J. Vaux (2001). Water Quality (Book Review). Environment 43 (3): 39.

[17] A. Parparov, K. D. Hambright, L. Hakanson and A. Ostapenia (2006). Water Quality Quantification: Basics and Implementation. Hydrobiologia, 560: 227 237.

[18] Atul M. Thakkar, Paras Tak, Madhaw Singh Chouhan, Naman Patel, "Physico - chemical Evolution of Water Quality at Pithampur Industrial Area during 2015 2016", International Journal of Science and Research (IJSR),

https: //www.ijsr.net/archive/v7i10/ART20191967. pdf, Volume 7 Issue 10, October 2018, 1012 - 1017 
[19] APHA (2012), Standard Methods for the Examination of Water and Waste Waters, 22nd Edition, American Public Health Association, Washington, DC.

[20] BIS (2012), Specifications for Drinking Water, IS: 10500: 2012, Bureau of Indian Standards, New Delhi.

[21] Wang W, Wang A, Chen L, Liu Y, Sun R. Effects of $\mathrm{pH}$ on Survival, Phosphorus Concentration, Adenylate Energy Charge and $\mathrm{Na}+-\mathrm{K}+$ ATPase Activities of Penaeus chinensis Osbeck Juveniles, aquatic Toxicology, 2002; 60: 75 - 83.

[22] S. Moscow, K. Jothivenkatachalam and P. Subramani, Der Chemica Sinica, 2011, 2 (2): 199 - 206.

[23] Hulyal, Kaliwal. Seasonal variations in physic chemical characteristics of Almatti reservoir of Bijapur district, Karnataka State. International journal of Environmental Protection.2011; 1 (1): 58 - 67.

[24] Thakre Gajanand, Jain Vikrant, and Gawande Sandeep, Department of Chemistry, Patel College of Science and Technology, Bhopal (MP), INDIA

[25] Muthukumaravel K. and et al., Evaluation of Ground Water Quality in Perambalur, Indian Journal of Environmental Sciences, 14 (1), 47 - 49 (2010)

[26] Preeti Gupta, Ranjeeta Choudhary and Monika Vishwakarma., Assessment of water quality of Kerwa and Kaliasote rivers at Bhopal district for irrigation purpose., International Journal of Theoretical \& Applied Sciences, 1 (2): 27 - 30 (2009) 